\title{
Solvent Optimization For Genistein Isolation Of "Rotten Tempe" By High Performance Liquid Chromatography Method
}

\author{
Cucun Alep Riyanto ${ }^{\text {a }}$, Hartati Soetjipto \\ Program Studi Kimia Fakultas Sains dan Matematika UKSW, Jalan Diponegoro 52 - 60 \\ Salatiga, Jawa Tengah 50711 \\ a)email: cucun.alep@staff.uksw.edu
}

\begin{abstract}
Genistein is a soy isoflavone that has been known have anticancer properties. The aim of this research is to determine the right combination of solvents to extract isoflavones in rotten tempe and determine the genistein content of the extraction process by the High Performance Liquid Chromatography (HPLC) method. Isoflavone extraction process was done using a mixture of methanol and chloroform solutions. Isoflavone extracts obtained will be analysed using High Performance Liquid Chromatography (HPLC) method to determine the content of genistein. The optimum isoflavone extract was obtained from chloroform:methanol $(10: 1 \mathrm{v} / \mathrm{v})$ solvent ratio. Where as the highest contents of genistein from the $4^{\text {th }}$ day "rotten tempe" as $26.199 \pm 25.146$ $(\mathrm{mg} / \mathrm{g})$.
\end{abstract}

Keywords: anti-cancer, extraction, isoflavone, genistein, rotten tempe

\begin{abstract}
ABSTRAK
Genistein merupakan salah satu isoflavon kedelai yang telah diketahui memiliki sifat antikanker. Tujuan penelitian adalah untuk menentukan kombinasi pelarut yang tepat untuk mengekstraksi isoflavon dalam tempe busuk dan menentukan kadar genistein tertinggi melalui proses ekstraksi dengan metode Kromatografi Cair Kinerja Tinggi (KCKT). Ekstraksi isoflavon menggunakan campuran larutan metanol dan kloroform. Ekstrak isoflavon yang diperoleh akan dianalisis menggunakan metode Kromatografi Cair Kinerja Tinggi (KCKT) untuk menentukan kandungan genistein. Hasil optimal untuk ekstraksi isoflavon adalah pada komposisi perbandingan pelarut kloroform: metanol $(10: 1 \mathrm{v} / \mathrm{v})$. Kadar genistein tertinggi dari "tempe busuk" ada pada hari ke-4 dengan nilai rerata adalah $26,199 \pm 25,146(\mathrm{mg} / \mathrm{g})$.
\end{abstract}

Kata-kata kunci: anti-kanker, ekstraksi, isoflavon, genistein, tempe busuk

\section{Pendahuluan}

Tanaman kedelai (Glycine max L. Merrill) dari famili leguminosae merupakan salah satu spesies tumbuhan yang mengandung senyawa isoflavon tinggi. Senyawa ini dikenal memiliki kesamaan molekul dengan estrogen. Kandungan senyawa lainnya seperti inhibitor protease, asam fitat, saponin, fitosterol, asam lemak omega-3, dan isoflavon juga memiliki bioaktivitas anti kanker. Dalam tanaman, isoflavon memiliki 4 bentuk isomer yaitu aglikon dan glukosida yang terdiri atas $\beta$ glukosida (genistein, daidzein, dan glisitein), asetil- $\beta$ - glukosida dan malonil$\beta$ - glukosida (Wang and Murphy, 1994). Proses fermentasi pada kedelai telah diketahui meningkatkan kadar isoflavon total, sehingga memperbesar

Solvent Optimization For Genistein Isolation Of "Rotten Tempe" By High 
peluang fungsi tempe sebagai pangan fungsional. Fermentasi yang lebih lama pada tempe memungkinkan kadar isoflavon juga akan meningkat, di mana pada proses ini tempe akan membusuk. Istilah "tempe busuk" atau tempe kadaluwarsa biasanya digunakan untuk tempe lewat 1-2 hari (Wang and Murphy, 1994). Saat ini, "tempe busuk" hanya dimanfaatkan sebagai salah satu bumbu dapur untuk kuliner tradisional Jawa Tengah khususnya daerah Semarang dan sekitarnya.

Klejdus et al. (2004) melaporkan bahwa kombinasi pelarut metanol:air (90:10\%, v/v) merupakan campuran pelarut terbaik dalam ekstraksi isoflavon dari sampel kedelai. Zhang et al. (2007) melakukan ekstraksi isoflavon dari tepung kedelai dengan pelarut etanol 4099,9\%, menghasilkan 0,62 mg isoflavon aglikon. Wang et al. (2013) melaporkan penelitian ekstraksi isoflavon dari biji kedelai dengan variasi pelarut dan suhu ekstraksi, diperoleh hasil bahwa proses ekstraksi terbaik dengan pelarut etanol $65 \%$ dalam suhu $70^{\circ} \mathrm{C}$.

Genistein yang merupakan salah satu isoflavon dalam kedelai, telah terbukti memiliki efek profilaksis dan sangat berpotensi sebagai penghambat efek kanker pada usus, lambung, paruparu, dan pankreas (Andres et al., 2011). Genistein mampu memberikan efek Solvent Optimization For Genistein Isolation Of "Rotten Tempe” By High Performance Liquid Chromatography Method

(Cucun Alep Riyanto, Hartati Soetjipto) pleiotropik melalui proses modulasi gen yang terkait dengan siklus sel dan apoptosis (Banerjee et al., 2008). Kandungan genistein dalam pangan kedelai bervariasi antara $0,2-1 \mathrm{mg} / \mathrm{g}$. Senyawa ini memiliki IC 50 antara $5-40$ $\mu \mathrm{M} / \mathrm{L}$ atau tidak beracun seperti senyawa antikanker pada umumnya yang sangat beracun dan mampu membunuh sel sehat lainnya (Polkowski and Mazurek, 2000).

Dalam perkembangan penelitian tentang kedelai dan kadar isoflavon, sejauh mana lama fermentasi berkaitan dengan peningkatan isoflavon pada tempe busuk/kadaluwarsa masih belum diketahui. Selain itu, akan dilakukan pengukuran kadar genistein melalui metode KCKT.

\section{Tujuan Penelitian}

Tujuan dari penelitian ini adalah sebagai berikut:

1. Menentukan kombinasi pelarut yang tepat untuk mengekstraksi isoflavon dalam tempe busuk.

2. Menentukan kadar genistein tertinggi melalui proses ekstraksi dengan metode KCKT.

\section{Metode Penelitian}

\section{Bahan}

Bahan tempe hari ke-0 diperoleh dari pengrajin tempe " $Y$ " di Kecamatan Gendongan, Salatiga. Bahan kimia yang dibutuhkan adalah metanol, etanol, 
heksan, etil asetat, $\mathrm{HCl}, \mathrm{CHCl}_{3}$, asetonitril, dan asam asetat gradient grade, semua dari E-Merck. Poliamid Sigma, isoflavon standard meliputi genistein (grade 98\%). Untuk plat Kromatografi Lapis Tipis digunakan plat silika gel ${ }_{60} \mathrm{~F}_{254}$, Merck, Jerman.

Alat

Piranti yang digunakan antara lain neraca analitis 4 digit (Mettler $\mathrm{H}$ 80, USA), neraca analitis 2 digit (Ohaus TAJ602,USA), blender (Philips HR2108, Belanda), moisture analyzer Ohaus MB 25, rotary evaporator (Buchi R0114, Swiss), drying cabinet (Bengkel Rekayasa Wangdi, Yogyakarta) dan HPLC (Knauer Smartline 5000, Smartline pump 1000, dan Smartline UV Detector 2500, Jerman).

\section{Preparasi Sampel}

Sampel tempe yang digunakan dari fermentasi hari ke- $0,1,2,3,4,5,6$, 7, dan 8 masing- masing dipotong tipistipis dan dikeringkan dengan drying cabinet pada suhu $50^{\circ} \mathrm{C}$ selama 2 hari, kemudian dihaluskan menggunakan grinder.

\section{Pengukuran Kadar Air}

Pengukuran kadar air dilakukan dengan memasukkan secara teliti kurang lebih $1 \mathrm{~g}$ sampel ke dalam moisture analyzer.
Ekstraksi Isoflavon (Purwoko (2004) yang dimodifikasi)

Seberat $50 \quad \mathrm{~g}$ tempe kering dimaserasi dalam metanol-80\% selama 9 jam. Setelah disaring, filtrat dievaporasi sampai kering. Ekstrak dilarutkan dalam $50 \mathrm{~mL}$ campuran metanol-50\% dan heksana $(1: 2, \mathrm{v} / \mathrm{v})$ untuk menghilangkan lemak secara partisi. Hasil separasi ekstrak fraksi polar dilarutkan dalam campuran metanol dan kloroform (1:1, v/v) kemudian dilakukan pemisahan kembali. Fraksi kloroform dievaporasi menghasilkan ekstrak kasar isoflavon.

Identifikasi

Menggunakan

Kromatografi Lapis Tipis (KLT)

(Hessler et al., 1997) yang dimodifikasi)

Analisis Kromatografi Lapis Tipis

(KLT) dilakukan dengan menggunakan fase diam plat silika gel $_{60} \mathrm{~F}_{254}$ dan fase gerak berupa campuran kloroform:metanol $(5: 1 \mathrm{v} / \mathrm{v}) ;(10: 1 \mathrm{v} / \mathrm{v})$; dan $(20: 1 \mathrm{v} / \mathrm{v})$. Pengamatan dilakukan di bawah sinar UV dengan panjang gelombang $254 \mathrm{~nm}$. Harga $\mathrm{R}_{\mathrm{f}}$ diukur, kemudian dibandingkan dengan harga $\mathrm{R}_{\mathrm{f}}$ standard.

Identifikasi Isoflavon (da Costa César et al. (2006) yang dimodifikasi)

Identifikasi isoflavon dengan menggunakan metode KCKT dilakukan dengan pengkondisian instrumen KCKT dan pembuatan larutan sampel. Larutan 
sampel dibuat dengan menimbang $0,1 \mathrm{~g}$ ekstrak lalu dilarutkan dalam metanol 5 $\mathrm{mL}$. Setelah larutan di-sentrifuge, diambil $20 \mu \mathrm{L}$ dengan alat injeksi. Kemudian sampel diinjeksikan ke dalam KCKT setelah pengkondisian KCKT selesai. Kromatogram KCKT dianalisis dengan menggunakan pembanding kromatogram isoflavon genistein standard.

\section{Instrumentasi}

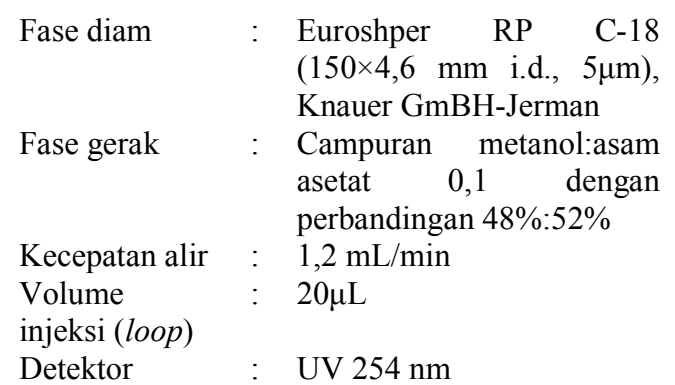

Analisis kuantitatif isoflavon (genistein) dilakukan dengan menghitung luas area kromatogram. Konsentrasi genistein dapat diketahui dengan menghitung persamaan garis dari kurva standard genistein.

\section{Hasil dan Pembahasan}

\section{Pengukuran Kadar Air}

Berdasarkan proses pengukuran kadar air pada serbuk tempe yang sudah dikeringkan, diperoleh hasil yang bervariasi pada tiap hari fermentasi. Hasil kadar air tertinggi adalah pada hari ke-7 fermentasi sebesar $4,654 \% \pm 0,576$ dari waktu fermentasi $0-8$ hari. Kadar air yang tinggi menandakan kenaikan aktivitas perombakan glukosa menjadi karbondioksida dan air, sehingga akan meningkatkan kadar air pada bahan kering (Fardiaz, 1992). Hasil lengkap pengukuran kadar air disajikan pada

\section{Tabel 1.}

Tabel 1. Hasil pengukuran kadar air tempe busuk

\begin{tabular}{cccccccccc}
\hline \multirow{2}{*}{ Kadar } & \multicolumn{8}{c}{ Hari Ke- } \\
\cline { 2 - 10 } Air (\%) & 0 & 1 & 2 & 3 & 4 & 5 & 6 & 7 & 8 \\
\cline { 2 - 12 } SE & $2,342 \pm$ & $2,819 \pm$ & $3,190 \pm$ & $4,221 \pm$ & $4,566 \pm$ & $3,917 \pm$ & $3,049 \pm$ & $4,654 \pm$ & $3,932 \pm$ \\
& 0,907 & 1,184 & 0,572 & 0,495 & 0,895 & 1,205 & 0,951 & 0,576 & 1,174 \\
\hline
\end{tabular}

\section{Ekstraksi Isoflavon}

Hasil ekstraksi isoflavon dari tempe busuk disajikan pada Gambar 1.

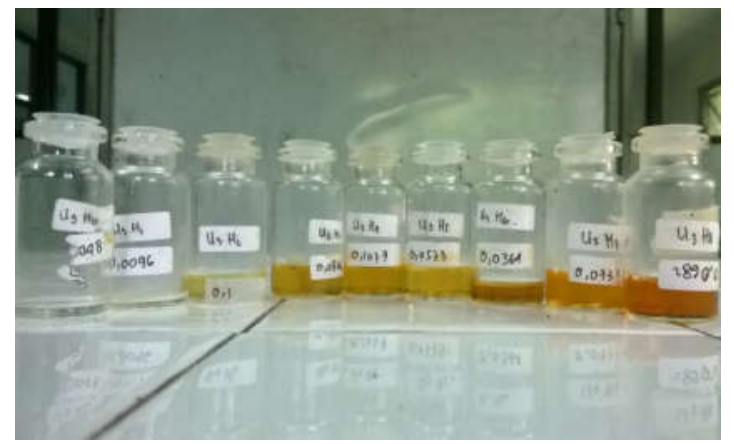

Gambar 1. Hasil ekstraksi isoflavon dari hari ke-0 s/d ke-8

Solvent Optimization For Genistein Isolation Of "Rotten Tempe" By High 
Hasil perhitungan kadar isoflavon tempe busuk disajikan dalam Tabel 2.

Tabel 2. Hasil pengukuran kadar isoflavon tempe busuk

\begin{tabular}{|c|c|c|c|c|c|c|c|c|c|}
\hline \multirow{2}{*}{ Kadar } & \multicolumn{10}{|c|}{ Hari Ke- } \\
\cline { 2 - 10 } Isoflavon & 0 & 1 & 2 & 3 & 4 & 5 & 6 & 7 & 8 \\
\cline { 2 - 10 }$(\mathrm{mg}) \pm$ & 18,535 & 56,727 & 30,513 & $60,567 \pm$ & $111,448 \pm$ & 44,333 & 45,333 & $71,456 \pm$ & $70,167 \pm$ \\
$\mathrm{SE}$ & $\pm 8,510$ & $\pm 7,127$ & $\pm 8,673$ & 14,547 & 15,682 & $\pm 9,015$ & $\pm 6,679$ & 8,489 & 15,303 \\
\hline
\end{tabular}

Berdasarkan Tabel 2, terlihat bahwa ekstrak kasar isoflavon tertinggi berada pada proses fermentasi hari ke-4 sejumlah 111,448 \pm 15,682 (g). Hasil ini dapat digunakan sebagai prediksi awal kadar isoflavon tertinggi yang nantinya akan diuji lebih lanjut menggunakan

\section{Identifikasi Menggunakan}

Kromatografi Lapis Tipis (KLT)

Hasil identifikasi isoflavon dengan metoda KLT pada berbagai perbandingan pelarut disajikan pada

\section{Gambar 2.}

\section{KCKT.}

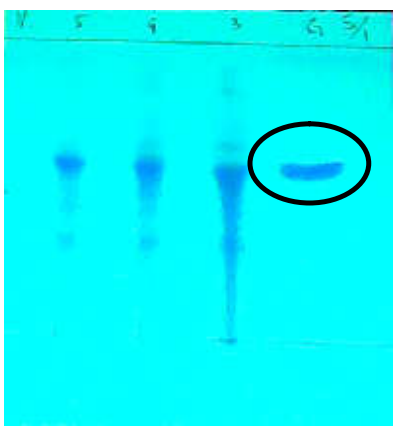

(a)

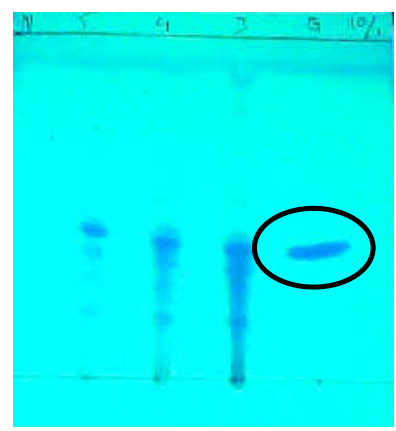

(b)

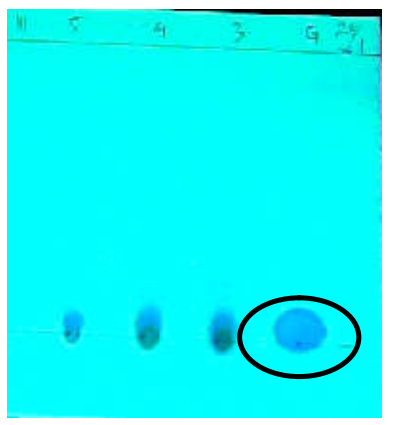

(c)

Gambar 2. Hasil Kromatografi Lapis Tipis dengan pelarut kloroform:metanol 5:1, v/v (a); $10: 1, \mathrm{v} / \mathrm{v}(\mathrm{b}) ;$ dan $20: 1, \mathrm{v} / \mathrm{v}$ (c)

Pada Gambar 2a dan 2b terlihat jelas pemisahan isoflavon dari eluen yang digunakan. Hasil pemisahan untuk sampel genistein standar berada pada sisi paling kanan untuk tiap perbandingan pelarut. Pada perbandingan pelarut kloroform:metanol (20:1 v/v) (Gambar 2c) tidak tampak terjadinya pemisahan karena pelarut kloroform dengan Solvent Optimization For Genistein Isolation Of "Rotten Tempe" By High Performance Liquid Chromatography Method perbandingan lebih tinggi sehingga lebih cepat menguap. Hasil identifikasi pada perbandingan pelarut kloroform:metanol $(10: 1, \mathrm{v} / \mathrm{v})$ sesuai dengan penelitian (Jyoti et al., 2015) di mana $\mathrm{Rf}$ dari genistein standar adalah 0,50.

\section{Identifikasi Isoflavon}

Setelah diketahui hasil optimal pemisahan isoflavon dalam pelarut 115 
kloroform: metanol, selanjutnya ekstrak isoflavon diuji dengan metode KCKT untuk mengidentifikasi isoflavon yang ada. Selain identifikasi, metode KCKT juga dilakukan untuk menentukan kadar isoflavon yang terkandung dalam ekstrak. Hasil uji kuantitatif ditampilkan pada

\section{Gambar 3.}

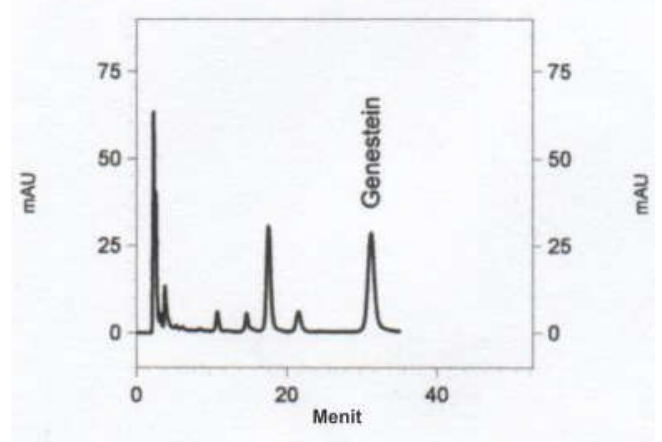

Gambar 3. Kadar genistein hasil analisa KCKT
$250 \times 4,6 \mathrm{~mm}(\mathrm{WL} 75))$ dan fasa gerak HOAc:metanol (52:48, $\mathrm{pH}=3,0)$ dengan laju rata-rata $1,2 \mathrm{~mL} /$ menit. Genistein diamati dengan absorbansi UV pada 254 nm. Berdasarkan Gambar 3, terlihat bahwa puncak genistein muncul pada waktu retensi 31,183 menit. Puncak pada waktu retensi tersebut merupakan identitas yang otentik untuk genistein (Fukutake et al., 1996).

Setelah diketahui bahwa dalam ekstrak isoflavon terkandung genistein, maka dilakukan penghitungan kadar genistein dalam tiap gram ekstrak isoflavon. Hasil penghitungan ditampilkan dalam Tabel 3.

Sampel ekstrak isoflavon diinjeksikan sejumlah $20 \quad \mu \mathrm{L}$ dalam kolom (Vertex, Eurospher 100-5 C18,

Tabel 3. Hasil pengukuran kadar genistein tempe busuk

\begin{tabular}{cccccccccc}
\hline \multirow{2}{*}{ Kadar } & \multicolumn{8}{c}{ Hari Ke- } \\
\cline { 2 - 10 } Genistein & 0 & 1 & 2 & 3 & 4 & 5 & 6 & 7 & 8 \\
\cline { 2 - 11 }$(\mathrm{mg} / \mathrm{g})$ & $0,150 \pm$ & $0,601 \pm$ & $1,121 \pm$ & $1,811 \pm$ & $26,199 \pm$ & $0,705 \pm$ & $2,053 \pm$ & $1,670 \pm$ & $1,645 \pm$ \\
& 0,081 & 0,374 & 0,892 & 0,823 & 25,146 & 0,094 & 0,960 & 0,825 & 0,851 \\
\hline
\end{tabular}

Berdasarkan Tabel 3, terlihat bahwa kadar genistein tempe busuk tertinggi adalah waktu fermentasi 4 hari yaitu $26,199 \pm 25,146(\mathrm{mg} / \mathrm{g})$. Hasil ini lebih tinggi daripada kadar genistein pada kacang kedelai dan susu kedelai yaitu 4,6 $\mu \mathrm{g} / \mathrm{g} \quad$ dan $\quad 13,9 \mu \mathrm{g} / \mathrm{g}$, berturut-turut (Fukutake et al., 1996). Kadar genistein Solvent Optimization For Genistein Isolation Of "Rotten Tempe" By High Performance Liquid Chromatography Method yang diperoleh dalam penelitian ini juga lebih tinggi dari penelitian (Jyoti et al., 2015) dengan kadar genistein sejumlah $1,0 \mathrm{mg} / \mathrm{mL}$ untuk biji kacang kedelai.

\section{Kesimpulan}

Berdasarkan penelitian yang telah dilakukan maka hasil ekstraksi isoflavon tempe busuk terbaik diperoleh pada 116 
perbandingan pelarut kloroform:metanol $(10: 1, \mathrm{v} / \mathrm{v})$ dan lama waktu fermentasi selama 4 hari dengan kadar genistein sebesar 26,199 $\pm 25,146(\mathrm{mg} / \mathrm{g})$.

\section{Ucapan Terima Kasih}

Terima kasih kepada UKSW yang telah memberikan dana penelitian untuk Penelitian Perseorangan/kelompok Wajib UKSW Tahun Anggaran 2016, Laboran Kimia, dan asisten peneliti yang telah membantu dalam terlaksananya penelitian ini.

\section{Daftar Pustaka}

Andres, S., Abraham, K., Appel, K. E. and Lampen, A., 2011, Risks and benefits of dietary isoflavones for cancer, Critical Reviews in Toxicology, 41(6), 463-506, doi: 10.3109/10408444.2010.541900.

Banerjee, S., Li, Y., Wang, Z. and Sarkar, F. H., 2008, Multi-targeted therapy of cancer by genistein, Cancer Letters, 269(2), 226-242, doi: 10.1016/j.canlet.2008.03.052.

da Costa César, I., Braga, F. C., Soares, C. D. V., de Aguiar Nunan, E., Pianetti, G. A., Condessa, F. A., Barbosa, T. A. F. and Campos, L. M. M., 2006, Development and validation of a RP-HPLC method for quantification of isoflavone aglycones in hydrolyzed soy dry extracts, Journal of Chromatography B, 836(1-2), 74-78, doi: 10.1016/j.jchromb.2006.03.030.

Fardiaz, S., 1992, Mikrobiologi Pangan, Gramedia Pustaka, Jakarta.
Fukutake, M., Takahashi, M., Ishida, K., Kawamura, H., Sugimura, T. and Wakabayashi, K., 1996, Quantification of genistein and genistin in soybeans and soybean products, Food and Chemical Toxicology, 34(5), 457-461, doi: 10.1016/0278-6915(96)87355-8.

Hessler, P. E., Larsen, P. E., Constantinou, A. I., Schram, K. H. and Weber, J. M., 1997, Isolation of isoflavones from soybased fermentations of the erythromycin-producing bacterium Saccharopolyspora erythraea, Applied Microbiology and Biotechnology, 47(4), 398404, doi: $10.1007 / \mathrm{s} 002530050947$.

Jyoti, Agrawal, S. S., Saxena, S. and Sharma, A., 2015, Phytoestrogen "Genistein ": Its Extraction and Isolation from Soybean Seeds, International Journal of Pharmacognosy and Phytochemical Reasearch, 7(6), 1121-1126.

Klejdus, B., Mikelová, R., Zehnálek, J., Vacek, J., Kizek, R. and Kubá V., 2004, Liquid chromatographic - mass spectrometric determination of genistin and daidzin in soybean food samples after accelerated solvent extraction with modified content of extraction cell, 517, 1-11, doi: 10.1016/j.aca.2004.05.003.

Polkowski, K. and Mazurek, A. P., 2000, Biological properties of genistein. A review of in vitro and in vivo data, Acta Poloniae Pharmaceutica, 57(2), 135-155.

Purwoko, T., 2004, Kandungan Isoflavon

Solvent Optimization For Genistein Isolation Of "Rotten Tempe" By High

Performance Liquid Chromatography Method 


\begin{abstract}
Aglikon pada Tempe Hasil Fermentasi Rhizopus microsporus var. oligosporus: Pengaruh Perendaman, BioSMART, 6(2), 85-87.
\end{abstract}

Wang, H. and Murphy, P. A., 1994, Isoflavone Content in Commercial Soybean Foods, Journal of Agricultural and Food Chemistry, 42(8), 1666-1673, doi: $10.1021 / \mathrm{jf00044a016.}$

Wang, M., Guo, J., Qi, W., Su, R. and He, Z., 2013, An Effective and Green Method for the Extraction and Purification of Aglycone Isoflavones from Soybean, Food Sci. Biotechnol., 22(3), 705-712, doi: 10.1007/s10068-013-0135-4.

Zhang, E. J., Ng, K. M. and Luo, K. Q., 2007, Extraction and Purification of Isoflavones from Soybeans and Characterization of Their Estrogenic Activities, J. Agric. Food. Chem., 55, 6940-6950, doi: $10.1021 /$ jf0708903

Solvent Optimization For Genistein Isolation Of "Rotten Tempe" By High

Performance Liquid Chromatography Method 